\title{
CONTRIBUTORS AND EDITORS
}

Ruth Bardel has recently taken up a lectureship at Reading University. In January 2000 she successfully submitted her DPhil at Oxford on Greek tragedy under the supervision of Dr Edith Hall.

Dr Simon Goldhill is Reader in Greek Literature and Culture at Cambridge University and Director of Studies at King's College, Cambridge. He has written widely on Greek literature and Greek culture. His publications include Language, Sexuality, Narrative, the Oresteia (1984), Reading Greek Tragedy (1986), The Poet's Voice (1991), Foucault's Virginity (1995) and (with Robin Osborne) Art and Text in Ancient Greek Culture (1994) and Performance Culture and Athenian Democracy (1999).

Professor Stephen Halliwell is Professor of Greek at St Andrews and is noted for his work in Greek dramatic theory and philosophy. His works include Aristotle's Poetics (1986), editions of Plato Republic 10 (1988) and Republic 5 (1993) and translations of Aristophanes' Birds, Lysistrata, Assembly-Women and Wealth (1997).

Dr Irene Lemos lectures at Edinburgh University and is one of the leading experts in the archaeology of Early Iron Age Greece. She has contributed to two volumes of the excavations of Lefkandi, Euboea: Lefkandi II (1990) and III (1996), and her book on the Protogeometric Aegean is in press at the Clarendon Press, Oxford. She is now preparing a monograph on the Ionian migration.

Dr Jenny March is an Associate Member of Corpus Christi, Oxford, and is interested in the connection between poetry, myth and images. She has published The Creative Poet (1987) and Cassell Dictionary of Classical Mythology (1998). She also edits the CA News.

Dr Elizabeth Moignard is Professor of Classical Art and Archaeology 
at Glasgow University. She has excavated in Greece and her main research interest is in Greek painted pottery. Her major publications are two volumes in the Corpus Vasorum Antiquorum series: Edinburgh (1989) and Glasgow (1997).

Professor Robin Osborne is a Fellow of Corpus Christi, Oxford, and a Greek historian of wide interests. His major publications are Demos: The Discovery of Classical Attica (1985), Classical Landscape with Figures (1987), Greece in the Making (1996) and Archaic and Classical Greek Art (1998). He is also joint editor of Art and Text in Ancient Greek Culture (1994), Placing the Gods (1994), Ritual, Finance, Politics, Athenian Democratic Accounts (1994) and Performance Culture and Athenian Democracy (1999).

Olga Palagia is Professor of Classical Archaeology at the University of Athens and a leading authority on Greek sculpture. Her publications include Euphranor (1980) and The Pediments of the Parthenon (1993). She has edited Greek Offerings in Honour of John Boardman (1997) and co-edited Sculpture from Arcadia and Laconia (1993), The Archaeology of Athens and Attica under the Democracy (1994), Personal Styles in Greek Sculpture (1996), Athenian Potters and Painters (1997) and Regional Schools in Hellenistic Sculpture (1998).

Dr Keith Rutter is Reader in Classics in the University of Edinburgh. He has published widely on the coinage and history of South Italy and Sicily in the Greek period. His publications include Campanian Coinages 475-380 BC (1979) and Greek Coinages of Southern Italy and Sicily (1997). He has also been responsible for steering the Italian fascicule of Historia Numorum towards publication by the British Museum Press.

Professor Anthony Snodgrass is Professor of Classical Archaeology in Cambridge and particularly noted for his work on Greece in the Dark Age and archaic periods. For many years he has been co-director of a major archaeological project in Boeotia. His publications include Early Greek Armour (1964), Arms and Armour of the Greeks (1967), The Dark Age of Greece (1971), Archaic Greece (1980), Narration and Allusion (1982), The Archaeology of Greece (1987 - based on his Sather lectures at Berkeley, California) and Homer and the Artists (1998 - based on his Geddes-Harrower lectures in Aberdeen).

Professor Brian Sparkes has recently retired from the Chair of Classical Archaeology at Southampton University. His main interests are in Greek pottery, and his publications include Black and Plain Pottery, The 
Athenian Agora XII (1970, with Lucy Talcott), Greek Art (New Surveys in the Classics, 1991), Greek Pottery: An Introduction (1991) and The Red and the Black: Studies in Greek Pottery (1996 - based on his GeddesHarrower lectures in Aberdeen). He has co-edited The Eye of Greece (1982) and edited Greek Civilization (1998).

Dr Karen Stears is a Lecturer at Edinburgh University and is noted for her work on funerary customs and gender studies. Her $\mathrm{PhD}$ thesis was entitled 'Woman and Family' (1993) and she has published a series of articles over the last few years, including 'Dead Women's Society: Constructing Female Gender in Classical Athenian Funerary Sculpture', in N. Spencer (ed.), Time, Tradition and Society in Greek Archaeology (1995).

Dr Jeremy Tanner is a Lecturer in Greek and Roman Art and Architecture in the Institute of Archaeology, University College London. He holds a degree in Classics from Cambridge and an MA in Sociology from the University of Pennsylvania. His PhD thesis was entitled 'The Invention of Art History: Religion, Society and Artistic Differentiation in Comparative Historical Perspective'. His recent publications have centred on art as expressive symbolism and on high culture in the Hellenistic/ Roman world. He is preparing a reader in the sociology of art. 